\title{
The impact of agricultural extension on farm production in resettlement areas of Zimbabwe
}

\author{
January 2001 \\ Trudy Owens, University of Oxford \\ John Hoddinott, Dalhousie University \\ Bill Kinsey, University of Zimbabwe and Free University Amsterdam
}

WPS/2001-6

\begin{abstract}
In this paper, we revisit the contested issue of the impact of agricultural extension on farm production. We exploit two features of the data available to us: its longitudinal nature and explicit measures of farmer ability. We find that after controlling for innate productivity characteristics and farmer ability either using household fixed effects estimation, or by including a measure of farmer ability and village fixed effects, access to agricultural extension services, defined as receiving one or two visits per agricultural year, raises the value of crop production by about 15 per cent. This parameter estimate is statistically significant. However, we also find variability in these parameter estimates across individual crop years, with the impact being markedly different in drought and non-drought years. Collectively, these results suggest that although access to farm-level extension visits does increase productivity even after controlling for innate productivity characteristics and farmer ability, results from single-year cross-sectional studies should be treated with caution
\end{abstract}

Address for correspondence: Trudy Owens, Centre for the Study of African Economies, Department of Economics, Manor Road Building, Oxford, OX1 3UQ, U.K.. Phone 01865 281444. Fax 01865281447

Email: Trudy.Owens@Economics.Oxford.ac.uk

Funding for data collection has been provided in Zimbabwe by the British Development Division in Central Africa, UNICEF, and the former Ministry of Lands, Resettlement and Rural Development. Additional support was provided by grants in the United Kingdom from the Nuffield Foundation, the Overseas Development Institute, and the Department for International Development (formerly ODA). Assistance has also been received from the International Food Policy Research Institute, the Food and Agriculture Organization (FAO), the Centre for the Study of African Economies at the University of Oxford, the Free University Amsterdam, and the Research Board of the University of Zimbabwe. In addition, Trudy Owens thanks the Economic and Social Research Council for her studentship grant. Errors are ours. 


\section{The impact of agricultural extension on farm production in resettlement areas of Zimbabwe}

\section{Introduction}

It is widely recognized that increasing agricultural production is, in many parts of the developing world an important component of a strategy to increase incomes, reduce hunger and contribute to the improvement in other measures of well being. Doing so requires improvements in the productivity of factors of production. As Birkhaeuser, Evenson and Feder (1991), Evenson (1998) and others have argued, agricultural extension represents a mechanism by which information on new technologies, better farming practices and better management can be transmitted to farmers. It is not surprising, therefore, that considerable amounts of funds, running into the hundreds of millions of dollars, are disbursed annually in support of agricultural extension. It is also not surprising that the impact of agricultural extension has received considerable attention. Birkhaeuser, Evenson and Feder (1991) review 15 studies published between 1970 and 1989 on the impact of extension (typically measured by some form of contact with an extension agent) on farm productivity (output per unit area) or output (expressed in physical or monetary terms). ${ }^{1}$ Restricting ourselves to only those studies that use linear regression techniques, their review reports 26 estimates. Eleven estimates are statistically significant at the $90 \%$ per cent confidence level or higher, with the highest estimate indicating that contact with extension services raises output by 27 per cent.

However, studies of the impact of extension are vulnerable to two sources of parameter bias. Consider the following simple linear regression model: $Y_{\mathrm{ijt}}=\gamma \cdot X_{\mathrm{ijt}}+\mathrm{B} \cdot \mathrm{Z}_{\mathrm{ijt}}+\mathrm{e}_{\mathrm{ijt}}$, where $Y_{i j t}$ is a measure of output for farm $i$, situated in locality $j$ at time $t, X_{i j t}$ is a measure of contact with extension services, $Z_{\mathrm{ijt}}$ is a vector of other relevant characteristics that affect farm output, $\mathrm{B}$ and $\gamma$ are parameters to be estimated and $e_{i j t}$ is a disturbance term of the form, $e_{i j t}=v_{j}+v_{i}+v_{i j t}$. Here, $v_{j}$ captures fixed characteristics of the locality not incorporated into $Z_{i j t}$, $v_{i}$ captures fixed characteristics of the farm not incorporated into $Z_{\mathrm{ijt}}$ and $\mathrm{v}_{\mathrm{ijt}}$ is a white noise disturbance term. One form of bias follows from endogenous program placement (Rosenzweig and Wolpin, 1986). Suppose governments decide to concentrate extension resources in highly productive areas and that this fixed locality characteristic is not controlled for in the linear regression. Consequently, via the correlation between $X_{\mathrm{ijt}}$ and $\mathrm{v}_{\mathrm{j}}, \mathrm{X}_{\mathrm{ijt}}$ and $\mathrm{e}_{\mathrm{ijt}}$ will be correlated, yielding biased estimates of $\gamma$. A vivid demonstration of this potential bias is found by comparing results reported in Bindlish and Evenson $(1993,1997)$ with Gautam and Anderson (1999). Bindlish and Evenson find that access to extension services, as measured by the log of the extension-staff-to-farms ratio, has a positive and statistically significant impact on the value of farm production in Kenya. Gautam and Anderson (1999), using the same data, argue that when district fixed effects are incorporated, this positive impact disappears.

The second bias is a form of selection bias. If better able or better skilled farmers are more likely to seek out extension services, or if extension agents prefer to seek out such individuals, and if this farm level characteristic is not taken into account, again $\mathrm{X}_{\mathrm{ijt}}$ and $\mathrm{e}_{\mathrm{ijt}}$ will be

\footnotetext{
${ }^{1}$ This review is updated in Evenson (1998).
} 
correlated (this time, via the correlation between $\mathrm{X}_{\mathrm{ijt}}$ and $\mathrm{v}_{\mathrm{i}}$ ) and again $\gamma$ will be a biased estimate of the impact of extension. Note that merely controlling for locality level fixed effects will not eliminate this correlation because differencing at the locality level does not eliminate the effect of $\mathrm{v}_{\mathrm{i}}$.

This study contributes to the literature on the impact of farmer contact with agricultural extension services on farm productivity, drawing on a unique panel sample of households residing in three resettlement areas of rural Zimbabwe. It pays particular attention to the potential confounding effects of the biases described above. Specifically, we exploit the longitudinal nature of our data to estimate the impact of extension on the value of crop production per hectare, with and without controls for unobservable household level fixed effects. The attraction of this estimator is that the differencing process rids the specification of the correlation between extension and the disturbance term. A further unique feature of these data is that we have extension worker assessments of farmers' ability. Exploiting these features, we find that after controlling for innate productivity characteristics and farmers' ability using household fixed effects estimation, access to agricultural extension services, defined as receiving one or two visits per agricultural year, raises the value of crop production by about 15 per cent. This parameter estimate is statistically significant. A similar result is obtained when we control for innate productivity using locality dummies and farm plot characteristics and farmers' ability using the assessments of ability provided by extension workers. However, we also find considerable variability in these parameter estimates across individual crop years.

\section{Study area and data}

Upon gaining independence in 1980, the Government of Zimbabwe announced a wide ranging programme of land reform designed to address the severe inequalities in land ownership between blacks and whites. A component of the programme was the resettlement of households on farms previously occupied by white commercial farmers. Households selected for the schemes included: refugees or other persons displaced by war, including extra-territorial refugees, urban refugees and former inhabitants of protected villages; those who were residing in communal areas but were landless; and those who had insufficient land to maintain themselves and their families. At the time of settlement, the household heads were also supposed to be married or widowed, aged 25 to 50 and not in formal employment. Each household was randomly allocated 5 hectares of arable land for cultivation, with the remaining area in each resettlement site being devoted to communal grazing land. Households were also allocated a residential plot within a planned village. Individuals settled on these schemes were required to renounce any claim to land elsewhere in Zimbabwe. They were not given ownership of the land on which they were settled (and hence could neither buy nor sell land within the resettlement area), but instead were given permits covering occupancy of homes and cultivation rights. In return for this allocation of land, the Zimbabwean government required male heads to earn their livelihoods exclusively from farming. Until 1992, male household heads were not permitted to work on other farms, nor could they migrate to cities, leaving their wives to work these plots.

The data used in this paper are drawn from a sample of households resettled in three regions of Zimbabwe. The initial sampling frame consisted of all resettlement schemes established in the first two years of the programme in Zimbabwe's three agriculturally most important agro-climatic zones. These are Natural Regions II, III and IV and correspond to areas of moderately high, moderate and restricted agricultural potential. One scheme was selected 
randomly from each zone: Mupfurudzi in Mashonaland Central Province (which lies to the north of Harare in NRII), Sengezi in Mashonaland East Province (which lies south east of Harare in NRIII) and Mutanda in Manicaland Province (which lies south east of Harare, but farther away than Sengezi and in NRIV). Random sampling was then used to select villages within schemes, and in each selected village, an attempt was made to cover all selected households.

These households were first interviewed over the period July-September 1983 to JanuaryMarch 1984. They are located in 20 different villages (two additional villages were added to the sample in 1993). Just over half (57 per cent) are found in Mupfurudzi with 18 per cent located in Mutanda and 25 per cent found in Sengezi. They were re-interviewed in the first quarter of 1987 and annually during January to April, since 1992. The analysis presented here is based on data collected from 1993 to 1997 . For these years, it is possible to regress a set of consistently defined regressors on a consistently defined dependent variable.

Specifically, the 1992/93 to 1995/96 survey rounds contained data on the following: crop production and yields; gross revenues from crop production; the value of the stock of agricultural tools (ox-ploughs, ox-carts, cultivators/harrowers, ox-planters, water carts, cotton sprayers, wheelbarrows, tractors and tractor equipment, hoes, axes, spades, machetes and slashers); ${ }^{2}$ land used in agricultural production; labour input, as measured by the number of people in the household between the ages of 15 and 64; the number of pairs of oxen owned by the household; levels of education; and rainfall by resettlement scheme. In addition, we have household level information on land quality, slope, soil type and distance to market. All monetary figures are expressed in 1992 Zimbabwe dollars using the CPI as a deflator.

During each interview, households were asked to report yield, sales and retention, for each crop, for the previous harvest. All physical quantities of output are converted to kilograms. Gross revenues from crop production are calculated by multiplying the physical quantities of output multiplied by their unit price. Unit prices were calculated for each household by dividing total sales value by the quantity sold. Where a household did not sell any of the crop, its total yield was multiplied by the median price received by farmers in that specific location.

Households planted, on average, two out of three of the following crops: maize, cotton, tobacco, sunflowers, groundnuts, nyimo (bambara nuts), rapoko, mhunga (small grains), and sorghum. Of these, maize is the most important source of cash income for the majority of households. In 1982/83, 92 per cent of farmers planted maize, 87 per cent in 1985/86, and 99 per cent in 1990/91 through to 1995/96. For households in Mupfurudzi, cotton is also an important source of cash income. ${ }^{3}$

The ideal measure of labour usage would be days worked, by person and activity. Unfortunately, this measure is not available for the survey years used here. As a crude proxy, available family labour supply - defined as the number of people in the household between the ages of 15 and 64 - is used. ${ }^{4}$ A related input, ownership of teams of oxen, is included. Teams of

\footnotetext{
${ }^{2}$ The construction of this variable is detailed in Gunning, Hoddinott, Kinsey and Owens (2000).

${ }^{3}$ It is worth making a brief note on costs of production and net crop income. While there is data available on fertilizer and pesticide use, as well as hired labour, it is not possible to break this down by maize and non-maize production. For this reason the results reported in the paper refer to gross crop figures. However, for total crop income we did estimate a net crop income regression which made no difference to the results. The results are available on request.

${ }^{4}$ We experimented with other measures of family labor supply. These did not alter our findings in any material
} 
oxen (defined as a pair, or span) permit fields to be prepared faster using a plough than by the alternative, individuals using hoes. They also allow farmers to improve the timing of planting by ensuring that fields will be prepared in advance of the early seasonal rains, and they typically make it possible to break up the soil to a greater depth. Average level of education of adult household members is included as a measure of household human capital. ${ }^{5}$ Finally, levels of rainfall recorded at the nearest station are included as a regressor. Unfortunately, there is only one rainfall observation per settlement scheme.

Table 1 provides some descriptive statistics for the sample and the key variables used in the estimations. Three dependent variables were chosen: the log of per-hectare maize yield; the log value of non-maize production per non-maize cropped hectare; and the log value of crop production per cropped hectare. The most important feature to note pertains to rainfall patterns across years. The first year of this sample, 1992/93, followed a disastrous season - the worst drought this century - and itself experienced somewhat below average rainfall. The next year was slightly worse, and 1994/95 was another drought year. This drought was somewhat unusual in that rainfall in the first few months of the season was at normal levels, but the rains ended early leading to significant drought-related crop losses. By contrast, the farmers in this sample experienced above average rains in the following year, 1995/96.

We now turn to access to extension. Mupfurudzi resettlement scheme is served by two extension agents. Mutanda, which is larger than Mupfurudzi, is also served by two extension officers, but they operate from different bases. Sengezi, which is considerably smaller in size, is served by a single agent. ${ }^{6}$ All extension staff focused on providing advice on cropping during the period covered by this paper, while a veterinary assistant (under a different government department) dealt separately with animal health issues. These agents conduct both group meetings as well as undertaking individual farm visits; however, respondents have indicated that in the majority of cases, the extension worker comes "on his own" rather than "at their request". In these individual visits, discussion typically focuses on issues relating to crop spacing and fertilizer application, though other issues such as fallowing, field contouring and crop rotation are also mentioned. About 80 per cent of farmers report that they follow the advice they are given. Over the period of this study, there is a decline in the percentage of households receiving extensions visits and in the mean number of visits. This is a consequence of a decline in transport funding to these workers. Although the number of extension workers did not change (in fact the same extension workers were in place throughout this period), there were significant cuts in transport allowances. Since these settlement schemes are rather dispersed, these cutbacks significantly reduced the ability of workers to reach individual farmers. Tables $2 \mathrm{a}$ and $2 \mathrm{~b}$ provide further data on these trends.

Two additional features of these households should also be noted. The relatively large amounts of land allocated to these households, together with the prohibitions on out-migration and the renunciation of land claims elsewhere in Zimbabwe meant that households had little

fashion.

${ }^{5}$ Using other measures, such as the education of the household head, or the highest level of schooling attained by any adult household member does not materially affect the results reported here.

\footnotetext{
${ }^{6}$ Subsequent to the period covered here, the national extension service began to adjust to staffing constraints by introducing greater specialization in specific areas of expertise on the part of field staff.
} 
incentive to leave these resettlement schemes. Consequently, there is remarkably little sample attrition. Approximately, 90 per cent of households who were first interviewed in 1983 and 1984 were re-interviewed in 1997. Second, the random allocation of households to plots of land, together with prohibitions on transfers, means that certain land characteristics such as distance to plots, number of plots, soil types and land slope, can be treated as exogenous.

\section{The impact of extension on crop production with controls for household fixed effects}

Tables 3, 4 and 5 report the impact of access to extension on three dependent variables: the log value of crop production per cropped hectare; the log of per-hectare maize yield; and the log value of non-maize production per non-maize cropped hectare. These estimates control for household holdings of agricultural capital stock, trained oxen (and its square), labour, land, education, plot characteristics and rainfall. Because of the way it is coded in the questionnaires, access to extension is measured via two dummy variables indicating whether the household receives one or two extension visits or three or more visits. For brevity, only the coefficients on extension are shown in these tables, along with their 95 per cent confidence intervals, but full results are available on request. The first four estimates reported in each table pertain to each individual crop year, with the fifth estimate being based on the pooled, 4-year sample. Time dummies are also included in the pooled specification. These results are based on least squares regressions with the standard errors robust to the possibility of intra-village correlations (Rogers, 1993; Deaton, 1997) and also to heteroscedasticity. The final estimate controls for both time effects, via year dummies, as well as unobserved household specific fixed effects.

There are five findings to note. Beginning with the final column in each table, after controlling for household fixed effects, rainfall, and characteristics that vary over time, such as capital stock, labour and land, one or two extension visits per cropping season has a statistically significant impact on the value of crop production. Using the formula provided by Halvorsen and Palmquist (1980), these visits raise the value of crop production per hectare of cropped area by 14.4 per cent. Second, this positive effect is found for both maize and non-maize production. Third, these fixed effects results show that there is no additional impact from receiving more than 1-2 visits.

The fourth finding is that, comparing the results for the fixed effects estimates with those obtained from simply pooling across all years, we find that the latter slightly understate the impact of extension on maize production and slightly overstate the impact on the value of nonmaize production. However, the confidence intervals for the parameter estimates with and without controls for household fixed effects overlap to a considerable extent. The estimates of impact in the pooled and fixed effects regressions on the value of all crops produced are nearly identical. Fifth, while the previous point might be taken to suggest that controlling for fixed effects is not important in assessing the effects of agricultural extension, an examination of the individual year estimates suggests otherwise. There is considerable variation in the parameter estimates across these different years. For example, looking at the results from 1993/94, one would be inclined to conclude that extension raised the value of non-maize production but not that of maize production. In 1995/96, extension raises the value of both maize and non-maize production. Although these variations exist across years, in the three non-drought years (1992/93, 1993/94 and 1995/96), the point estimates for the impact of 1-2 visits in any one year typically lie within the $95 \%$ confidence intervals for the other two years. But the impact is considerably different in the drought year of 1994/95. Recall that this particular drought was rather odd; a 
consequence of the failure of rains mid to late in the season rather than at the beginning. Consequently, farmers who received visits early in the season, before it was known that a drought would occur, and who, for example, followed extension advice to use fertilizers, were vulnerable to income losses. Once it became clear that the late rains were not going to continue in the usual pattern, extension staff altered their recommendations and advised farmers not to top-dress fertilizer on standing crops and to plant additional small areas of unfertilized maize following sporadic showers. Farmers, in turn, concentrated on saving their maize crops in an attempt to compensate for the certainty of lower yields. Hence those farmers who received extension visits late in the season (who tended to be those farmers who received 3 or more visits) were able to use this technical advice to adjust their practices and thereby salvage some of their maize harvest. This is consistent with the findings that for 1994/95, one or two visits had no, or a negative effect, on production, but also why those farmers receiving three or more visits had higher levels of maize production.

From these results, we draw two conclusions. First, even after controlling for unobserved household fixed effects, we find a statistically significant impact of extension visits on farm productivity. Second, as there appears to be variation in impact from year to year, relying on a single year's observations can mislead. ${ }^{7}$

\section{The impact of extension on crop production with controls for farmer ability}

In the introduction, we noted that estimates of the impact of extension visits on crop production may be biased if unobserved farmer skill or ability is not taken into account. In the previous section, this unobservable characteristic was "differenced out" via household level fixed effects estimation. In this section, we complement those results by directly including measures of farmer ability.

These measures were obtained on two occasions. In June 1995, extension agents serving this sample were asked to rank each farmer on a scale of 1 to 5 , with 1 representing low levels of ability, 3 representing "average" skill and a 5 denoting an "excellent" farmer. These rankings produced the following distribution of farmer ability: 12.8 percent of farmers were ranked as poor; 23.6 per cent were ranked as below average; 38.7 per cent were ranked as average; 16.6 per cent were ranked as above average; and 8.3 per cent were ranked as excellent. These rankings are included as a set of dummy variables; alternatively, including them as a continuous variable running from 1 to 5 has no substantive effect on our results. In June 1997, we conducted a series of participatory rural appraisal exercises in 13 of the 22 villages in our sample. A component of this work involved asking extension agents working in these resettlement areas to rank households. Our initial intention was to have these individuals rank households on the basis of wealth and compare these rankings with those made by other community members. However, while the extension agents were willing to undertake this exercise, they indicated that could only do so by ranking farmers according to their perceptions of farmer ability. The extension worker was allowed to choose the number of ranking categories. Two of the extension workers ranked on a scale of 1 to 3 , the other 2 on a scale of 1 to 4 , with lower numbers reflecting a perception of poorer farming ability. In light of the use of different scales, we made the rankings comparable across agents by dividing the rankings by the number of categories. Hence the variable goes from

\footnotetext{
${ }^{7}$ We also included year dummies interacted with the extension variables in the pooled and fixed effects estimations. This did not alter the results.
} 
0.25 to 1 . We note that there is evidence of considerable stability in these rankings. The Spearman correlation coefficient for farmers ranked in 1995 and 1997 is 0.65 .

Table 6 reports the results of controlling for farmer ability using the 1995 survey of farmer ability. Table 7 reports comparable results using the results from the smaller 1997 survey of abilities. In both cases, we estimate the same set of regressions, with the same specifications, as those reported in Tables 3 to 5. For brevity we only report the results for the impact of agricultural extension on log value of crop production per hectare of cropped area. As before, receiving only 1-2 extension visits had a statistically significant impact on crop production and hence only these results are reported in Tables 6 and 7. We begin with a comparison of pooled estimates, with household level fixed effects regressions. The first result for the pooled sample shows the impact of access to extension services without controls for either farmer ability or location. Controls for farmer ability, or farmer ability and village (but not household) fixed effects, are added in the next columns. The final column shows the impact of agricultural extension when we treat farmer ability and location as part of an unobservable household fixed effect. In both Tables 6 and 7, the parameter estimates for the household level fixed effects regressions are nearly identical to that reported for the pooled estimates with controls for ability and village fixed effects. However, when we look at the results by individual crop year, we again see a similar pattern to that reported in Table 3-in non-drought years, 1-2 visits by an extension worker increase income but with variations in the point estimates obtained. In the drought year the impact on income is negative, whether or not farming ability is included in the specification.

\section{Conclusions}

In this paper, we revisit the contested issue of the impact of agricultural extension on farm production. We exploit two features of the data available to us: its longitudinal nature and explicit measures of farmer ability. We find that after controlling for innate productivity characteristics and farmer ability either using household fixed effects estimation, or by including a measure of farmer ability and village fixed effects, access to agricultural extension services, defined as receiving one or two visits per agricultural year, raises the value of crop production by about 15 per cent. This parameter estimate is statistically significant. However, we also find variability in these parameter estimates across individual crop years, with the impact being markedly different in drought and non-drought years. Collectively, these results suggest that although access to farm-level extension visits does increase productivity even after controlling for innate productivity characteristics and farmer ability, results from single-year cross-sectional studies should be treated with caution. 
Table 1: Descriptive statistics

\begin{tabular}{|c|c|c|c|c|c|}
\hline & $1992 / 93$ & 1993/94 & $1994 / 95$ & $1995 / 96$ & Pooled \\
\hline \multicolumn{6}{|l|}{ Dependent variables } \\
\hline log maize production per maize & 6.603 & 6.327 & 5.130 & 6.664 & 6.267 \\
\hline cropped area & $(0.847)$ & $(0.911)$ & $(1.197)$ & $(0.778)$ & $(1.082)$ \\
\hline log value of maize production per & 6.494 & 6.203 & 5.232 & 6.802 & 6.262 \\
\hline maize cropped area & $(0.856)$ & $(0.901)$ & $(1.210)$ & $(0.736)$ & $(1.065)$ \\
\hline log value of non-maize production & 6.264 & 6.509 & 5.990 & 7.084 & 6.505 \\
\hline per non-maize cropped area & $(1.075)$ & $(1.051)$ & $(1.125)$ & $(1.132)$ & $(1.164)$ \\
\hline log value of crop production per & 6.286 & 6.018 & 5.150 & 6.251 & 5.989 \\
\hline cropped area & $(0.788)$ & $(0.830)$ & $(0.943)$ & $(0.776)$ & $(0.927)$ \\
\hline \multicolumn{6}{|l|}{ Independent variables } \\
\hline \multirow[t]{2}{*}{$\log$ of capital } & 7.727 & 7.792 & 7.883 & 7.886 & 7.818 \\
\hline & $(0.608)$ & $(0.594)$ & $(0.579)$ & $(0.613)$ & $(0.603)$ \\
\hline \multirow[t]{2}{*}{ pairs of trained oxen } & 1.249 & 1.316 & 1.274 & 1.296 & 1.285 \\
\hline & $(0.869)$ & $(1.000)$ & $(1.011)$ & $(1.249)$ & $(1.046)$ \\
\hline \multirow[t]{2}{*}{ pairs of trained oxen squared } & 2.313 & 2.730 & 2.641 & 3.237 & 2.744 \\
\hline & $(3.218)$ & $(4.316)$ & $(4.986)$ & $(8.529)$ & $(5.719)$ \\
\hline \multirow[t]{2}{*}{$\log$ of labour } & 1.425 & 1.488 & 1.478 & 1.518 & 1.478 \\
\hline & $(0.552)$ & $(0.510)$ & $(0.539)$ & $(0.519)$ & $(0.530)$ \\
\hline \multirow[t]{2}{*}{ log of maize cropped area } & 1.414 & 1.460 & 1.535 & 1.472 & 1.465 \\
\hline & $(0.449)$ & $(0.421)$ & $(0.403)$ & $(0.434)$ & $(0.430)$ \\
\hline \multirow[t]{2}{*}{ log of non-maize cropped area } & 1.123 & 1.073 & 1.045 & 1.143 & 1.100 \\
\hline & $(0.768)$ & $(0.737)$ & $(0.798)$ & $(0.705)$ & $(0.749)$ \\
\hline \multirow[t]{2}{*}{ log of total cropped area } & 2.062 & 2.060 & 2.092 & 2.077 & 2.071 \\
\hline & $(0.394)$ & $(0.366)$ & $(0.411)$ & $(0.411)$ & $(0.395)$ \\
\hline \multirow[t]{2}{*}{ Average education } & 6.604 & 6.843 & 7.079 & 7.090 & 6.893 \\
\hline & $(2.079)$ & $(2.281)$ & $(1.841)$ & $(1.762)$ & $(2.018)$ \\
\hline$\%$ of households with flat land & 37 & 38 & 36 & 38 & 38 \\
\hline$\%$ of households with sandy soil & 46 & 46 & 46 & 46 & 46 \\
\hline$\%$ of households with clay soil & 27 & 26 & 28 & 26 & 27 \\
\hline$\%$ of households with loam soil & 27 & 28 & 26 & 28 & 27 \\
\hline \multirow{2}{*}{$\begin{array}{l}\text { Walking distance (minutes) from } \\
\text { plot to homestead }\end{array}$} & 32.92 & 33.38 & 32.49 & 32.72 & 32.91 \\
\hline & $(22.75)$ & $(23.34)$ & $(21.95)$ & $(22.90)$ & $(22.78)$ \\
\hline \multirow{4}{*}{$\begin{array}{l}\text { Distance }(\mathrm{km}) \text { from homestead to } \\
\text { market } \\
\text { log of rainfall }\end{array}$} & 8.146 & 8.096 & 7.521 & 8.073 & 7.994 \\
\hline & $(4.970)$ & $(4.868)$ & $(4.726)$ & $(4.951)$ & (4.892) \\
\hline & 6.554 & 6.557 & 6.166 & 6.640 & 6.505 \\
\hline & $(0.085)$ & $(0.098)$ & $(0.155)$ & $(0.072)$ & $(0.197)$ \\
\hline Sample size & 339 & 343 & 243 & 356 & 1281 \\
\hline
\end{tabular}

Note: Standard deviations in brackets. 
Table 2a: Number of extension visits to farmers' residence, 1992/93 - 1995/96

\begin{tabular}{|c|c|c|c|c|c|}
\hline \multirow{2}{*}{$\begin{array}{l}\text { Agricultural } \\
\text { year }\end{array}$} & \multirow{2}{*}{$\begin{array}{l}\% \text { of households that } \\
\text { received at least one } \\
\text { extension visit p.a. }\end{array}$} & \multicolumn{4}{|c|}{ Average number of visits per year } \\
\hline & & Total sample & Mupfurudzi & Mutanda & Sengezi \\
\hline 1992/93 & 85 & $4.0 \quad(4.7)$ & $2.8 \quad(3.6)$ & $6.5(7.0)$ & $4.8 \quad(5.2)$ \\
\hline $1993 / 94$ & 60 & $1.9(3.1)$ & $1.9 \quad(3.3)$ & $2.3 \quad(3.1)$ & $1.5 \quad(2.8)$ \\
\hline $1994 / 95$ & 53 & $1.6 \quad(3.0)$ & $1.1 \quad(2.5)$ & $2.9 \quad(3.7)$ & $1.9 \quad(3.2)$ \\
\hline $1995 / 96$ & 62 & $1.4 \quad(2.2)$ & $1.5 \quad(2.3)$ & $1.7(2.4)$ & $1.0 \quad(2.5)$ \\
\hline
\end{tabular}

Notes: Figure in brackets is average number of visits if household received at least 1 visit.

Table 2b: Proportion of households receiving extension visits by crop year

\begin{tabular}{llllll}
\hline & $1992 / 93$ & $1993 / 94$ & $1994 / 95$ & $1995 / 96$ & Pooled sample \\
\hline at least 1 or 2 extension visits & 0.841 & 0.614 & 0.543 & 0.630 & 0.662 \\
3 or more extension visits & 0.500 & 0.216 & 0.349 & 0.295 & 0.336 \\
\hline
\end{tabular}


Table 3: The impact of agricultural extension on log value of crop production per cropped hectare

\begin{tabular}{|c|c|c|c|c|c|c|}
\hline & 1992/93 & $1993 / 94$ & $1994 / 95$ & $1995 / 96$ & $\begin{array}{l}\text { Pooled } \\
\text { sample }\end{array}$ & $\begin{array}{l}\text { Fixed } \\
\text { effects } \\
\text { estimates }\end{array}$ \\
\hline 1-2 extension visits & $\begin{array}{l}0.202 * * \\
(2.411)\end{array}$ & $\begin{array}{l}0.167 * * \\
(2.150)\end{array}$ & $\begin{array}{l}-0.223 * * \\
(2.005)\end{array}$ & $\begin{array}{l}0.247 * * \\
(2.720)\end{array}$ & $\begin{array}{l}0.165^{* * *} \\
(3.863)\end{array}$ & $\begin{array}{l}0.135 * * \\
(2.692)\end{array}$ \\
\hline $95 \%$ confidence & 0.028 & 0.005 & -0.454 & 0.058 & 0.076 & 0.037 \\
\hline $\begin{array}{l}\text { interval for " } 1-2 \\
\text { extension visits" }\end{array}$ & $0 . \overline{376}$ & $0 . \overline{329}$ & 0.008 & 0.436 & $0 . \overline{253}$ & $0 . \overline{234}$ \\
\hline $\begin{array}{l}3 \text { or more extension } \\
\text { visits }\end{array}$ & $\begin{array}{l}-0.022 \\
(0.273)\end{array}$ & $\begin{array}{l}0.050 \\
(0.549)\end{array}$ & $\begin{array}{l}0.259 \\
(1.744)^{*}\end{array}$ & $\begin{array}{l}-0.038 \\
(0.612)\end{array}$ & $\begin{array}{l}-0.009 \\
(0.174)\end{array}$ & $\begin{array}{l}-0.015 \\
(0.308)\end{array}$ \\
\hline $\begin{array}{l}\text { F-statistic (null: all } \\
\text { regressors are jointly } \\
\text { zero) }\end{array}$ & $20.91 * * *$ & $22.90 * * *$ & $7.53 * * *$ & $12.97 * * *$ & $103.52 * * *$ & $64.08 * * *$ \\
\hline R-squared & 0.413 & 0.362 & 0.230 & 0.293 & 0.427 & 0.274 \\
\hline $\begin{array}{l}\text { F-statistic on } \\
\text { household fixed } \\
\text { effects }\end{array}$ & & & & & & $2.62 * * *$ \\
\hline
\end{tabular}

Notes:

1. Regressors included but not reported are: $\log$ of capital, span of trained oxen, span of trained oxen squared, log of labour, log of area cropped, average years of education among adults, dummy variables for land sloped, soils are sandy, soils are clay, distance from plot to homestead, distance from homestead to market and log of rainfall.

2. Pooled and fixed effects estimates include year dummies.

3. Sample sizes: 1992/93 - 339; 1993/94 - 343; 1994/95 - 243; 1995/96 - 356; pooled sample 1281.

4. F-statistic and absolute values of $t$ statistics are calculated from robust standard errors in the presence of intra-cluster correlation at the village level (Rogers, 1993).

5 . *** significant at the 1 per cent level; ** at the 5 per cent level; * at the 10 per cent level. 
Table 4: The impact of agricultural extension on log hectare maize yield

\begin{tabular}{|c|c|c|c|c|c|c|}
\hline & 1992/93 & 1993/94 & $1994 / 95$ & $1995 / 96$ & $\begin{array}{l}\text { Pooled } \\
\text { sample }\end{array}$ & $\begin{array}{l}\text { Fixed } \\
\text { effects } \\
\text { estimates }\end{array}$ \\
\hline $1-2$ extension visits & $\begin{array}{l}0.094 \\
(0.995)\end{array}$ & $\begin{array}{l}0.096 \\
(1.027)\end{array}$ & $\begin{array}{l}-0.151 \\
(0.894)\end{array}$ & $\begin{array}{l}0.206 * * \\
(2.328)\end{array}$ & $\begin{array}{l}0.124^{*} \\
(1.853)\end{array}$ & $\begin{array}{l}0.181 * * * \\
(2.765)\end{array}$ \\
\hline $95 \%$ confidence & -0.103 & -0.098 & -0.502 & 0.022 & -0.015 & 0.053 \\
\hline $\begin{array}{l}\text { interval for " } 1-2 \\
\text { extension visits" }\end{array}$ & $0 . \overline{291}$ & $0 . \overline{-} \cdot 291$ & 0.200 & $\overline{-}-$ & $0 . \overline{263}$ & $0 . \overline{310}$ \\
\hline $\begin{array}{l}3 \text { or more extension } \\
\text { visits }\end{array}$ & $\begin{array}{l}-0.077 \\
(0.875)\end{array}$ & $\begin{array}{l}0.109 \\
(0.777)\end{array}$ & $\begin{array}{l}0.456 \\
(2.159)^{* *}\end{array}$ & $\begin{array}{l}0.058 \\
(0.615)\end{array}$ & $\begin{array}{l}0.037 \\
(0.548)\end{array}$ & $\begin{array}{l}-0.0001 \\
(0.572)\end{array}$ \\
\hline $\begin{array}{l}\text { F-statistic (null: all } \\
\text { regressors are jointly } \\
\text { zero) }\end{array}$ & $21.43 * * *$ & $26.48 * * *$ & $19.61 * * *$ & $24.87 * * *$ & $133.95 * * *$ & $66.83 * * *$ \\
\hline R-squared & 0.301 & 0.275 & 0.169 & 0.151 & 0.390 & 0.282 \\
\hline $\begin{array}{l}\text { F-statistic on } \\
\text { household fixed } \\
\text { effects }\end{array}$ & & & & & & $1.77 * * *$ \\
\hline
\end{tabular}

Notes:

1. Regressors included but not reported are: log of capital, span of trained oxen, span of trained oxen squared, log of labour, log of area cropped, average years of education among adults, dummy variables for land sloped, soils are sandy, soils are clay, distance from plot to homestead, distance from homestead to market and log of rainfall

2. Pooled and fixed effects estimates include year dummies.

3. Sample sizes: 1992/93 - 339; 1993/94 - 343; 1994/95 - 243; 1995/96 - 356; pooled sample - 1281.

4. F-statistic and absolute values of $t$ statistics are calculated from robust standard errors in the presence of intra-cluster correlation at the village level (Rogers, 1993).

5. *** significant at the 1 per cent level; ** at the 5 per cent level; * at the 10 per cent level. 
Table 5: The impact of agricultural extension on log of value of non-maize production per hectare

of non-maize cropped area

\begin{tabular}{|c|c|c|c|c|c|c|}
\hline & $1992 / 93$ & $1993 / 94$ & $1994 / 95$ & $1995 / 96$ & $\begin{array}{l}\text { Pooled } \\
\text { sample }\end{array}$ & $\begin{array}{l}\text { Fixed } \\
\text { effects } \\
\text { estimates }\end{array}$ \\
\hline 1-2 extension visits & $\begin{array}{l}0.174 \\
(1.263)\end{array}$ & $\begin{array}{l}0.315 * * * \\
(3.829)\end{array}$ & $\begin{array}{l}-0.189 \\
(1.126)\end{array}$ & $\begin{array}{l}0.293 * * \\
(2.351)\end{array}$ & $\begin{array}{l}0.262 * * * \\
(6.115)\end{array}$ & $\begin{array}{l}0.187 * * * \\
(2.857)\end{array}$ \\
\hline $95 \%$ confidence & -0.112 & 0.144 & -0.540 & 0.034 & 0.173 & 0.058 \\
\hline interval for "1-2 & - & - & - & - & - & - \\
\hline extension visits" & 0.460 & 0.485 & 0.161 & 0.553 & 0.352 & 0.315 \\
\hline $\begin{array}{l}3 \text { or more extension } \\
\text { visits }\end{array}$ & $\begin{array}{l}-0.083 \\
(0.667)\end{array}$ & $\begin{array}{l}-0.026 \\
(0.215)\end{array}$ & $\begin{array}{l}0.093 \\
(0.499)\end{array}$ & $\begin{array}{l}-0.091 \\
(0.757)\end{array}$ & $\begin{array}{l}-0.089 \\
(1.205)\end{array}$ & $\begin{array}{l}-0.086 \\
(-1.355)\end{array}$ \\
\hline $\begin{array}{l}\text { F-statistic (null: all } \\
\text { regressors are } \\
\text { jointly zero) }\end{array}$ & $52.03 * * *$ & $22.70 * * *$ & $60.68 * * *$ & $25.35 * * *$ & $120.38 * * *$ & $35.49 * * *$ \\
\hline R-squared & 0.308 & 0.379 & 0.180 & 0.316 & 0.347 & 0.079 \\
\hline $\begin{array}{l}\text { F-statistic on } \\
\text { household fixed } \\
\text { effects }\end{array}$ & & & & & & $2.93 * * *$ \\
\hline
\end{tabular}

Notes:

1. Regressors included but not reported are: log of capital, span of trained oxen, span of trained oxen squared, log of labour, log of area cropped, average years of education among adults, dummy variables for land sloped, soils are sandy, soils are clay, distance from plot to homestead, distance from homestead to market and log of rainfall.

2. Pooled and fixed effects estimates include year dummies.

3. Sample sizes: 1992/93 - 339; 1993/94 - 343; 1994/95 - 243; 1995/96 - 356; pooled sample - 1281.

4. F-statistic and absolute values of $t$ statistics are calculated from robust standard errors in the presence of intra-cluster correlation at the village level (Rogers, 1993).

5. *** significant at the 1 per cent level; ** at the 5 per cent level; * at the 10 per cent level. 
Table 6: The impact of agricultural extension on log value of crop production per hectare of cropped area: with and without farmer ability as measured in June 1995

\begin{tabular}{|c|c|c|c|c|c|c|c|c|c|c|c|c|c|}
\hline & \multicolumn{2}{|l|}{$1992 / 93$} & \multicolumn{2}{|l|}{$1993 / 94$} & \multicolumn{2}{|l|}{$1994 / 95$} & \multicolumn{2}{|l|}{$1995 / 96$} & \multicolumn{4}{|c|}{ Pooled sample } & \multirow[t]{2}{*}{ Fixed effects } \\
\hline & $\begin{array}{l}\text { Without } \\
\text { ability } \\
\text { variable }\end{array}$ & $\begin{array}{l}\text { With } \\
\text { ability } \\
\text { variable }\end{array}$ & $\begin{array}{l}\text { Without } \\
\text { ability } \\
\text { variable }\end{array}$ & $\begin{array}{l}\text { With } \\
\text { ability } \\
\text { variable }\end{array}$ & $\begin{array}{l}\text { Without } \\
\text { ability } \\
\text { variable }\end{array}$ & $\begin{array}{l}\text { With } \\
\text { ability } \\
\text { variable }\end{array}$ & $\begin{array}{l}\text { Without } \\
\text { ability } \\
\text { variable }\end{array}$ & $\begin{array}{l}\text { With } \\
\text { ability } \\
\text { variable }\end{array}$ & $\begin{array}{l}\text { Without } \\
\text { ability } \\
\text { variable or } \\
\text { village } \\
\text { dummies }\end{array}$ & $\begin{array}{l}\text { With } \\
\text { ability } \\
\text { variable, } \\
\text { without } \\
\text { village } \\
\text { dummies }\end{array}$ & $\begin{array}{l}\text { Without } \\
\text { ability } \\
\text { variable, } \\
\text { With } \\
\text { village } \\
\text { dummies }\end{array}$ & $\begin{array}{l}\text { With } \\
\text { ability } \\
\text { variable } \\
\text { and } \\
\text { village } \\
\text { dummies }\end{array}$ & \\
\hline $1-2$ ext. & $0.211 * *$ & $0.227 * * *$ & $0.186^{* *}$ & $0.139 *$ & $-0.218 *$ & $-0.255^{*}$ & $0.260 * * *$ & $0.232 * *$ & $0.176^{* * *}$ & $0.155^{* * *}$ & $0.148 * * *$ & $0.137 * * *$ & $0.151 * * *$ \\
\hline visits & $(2.809)$ & $(2.979)$ & $(2.235)$ & (1.773) & $(-1.997)$ & $(-1.995)$ & $(2.895)$ & $(2.598)$ & $(4.037)$ & $(3.469)$ & $(3.293)$ & $(3.044)$ & $(2.883)$ \\
\hline Ability $=2$ & & $\begin{array}{l}0.116 \\
(0.896)\end{array}$ & & $\begin{array}{l}-0.166 \\
(-1.237)\end{array}$ & & $\begin{array}{l}-0.242 \\
(-1.157)\end{array}$ & & $\begin{array}{l}0.330 * * \\
(2.408)\end{array}$ & & $\begin{array}{l}0.045 \\
(0.431)\end{array}$ & & $\begin{array}{l}0.106 \\
(0.997)\end{array}$ & \\
\hline Ability $=3$ & & 0.128 & & -0.160 & & -0.159 & & $0.296 * *$ & & 0.066 & & 0.085 & \\
\hline (average) & & $(0.951)$ & & $(-1.516)$ & & $(-0.612)$ & & $(2.350)$ & & $(0.591)$ & & $(0.745)$ & \\
\hline Ability $=4$ & & $0.298^{*}$ & & 0.164 & & 0.359 & & $0.586^{* * *}$ & & $0.360 * * *$ & & $0.379 * * *$ & \\
\hline & & $(1.878)$ & & $(1.066)$ & & $(1.637)$ & & $(3.937)$ & & $(3.165)$ & & $(3.266)$ & \\
\hline Ability $=5$ & & $0.475 * * *$ & & $0.489 * * *$ & & 0.390 & & $0.789 * * *$ & & $0.557 * * *$ & & $0.479 * * *$ & \\
\hline (excellent) & & (2.979) & & $(3.030)$ & & (1.681) & & $(5.760)$ & & $(5.159)$ & & $(4.178)$ & \\
\hline
\end{tabular}

Notes:

1. Dummy variables for extension workers' assessment of farmer ability on a scale of 1 (poorest) to 5 (excellent), with category 1 excluded

2. Regressors included but not reported are: log of capital, span of trained oxen, span of trained oxen squared, log of labour, log of area cropped, average years of education among adults, dummy variables for land sloped, soils are sandy, soils are clay, distance from plot to homestead, distance from homestead to market and log of rainfall.

3. Pooled and fixed effects estimates include year dummies.

4. Sample sizes: 1992/93 - 320; 1993/94 - 324; 1994/95 - 215; 1995/96 - 333; pooled sample - 1210.

5. F-statistic and absolute values of $t$ statistics are calculated from robust standard errors in the presence of intra-cluster correlation at the village level (Rogers, 1993).

6. *** significant at the 1 per cent level; ** at the 5 per cent level; * at the 10 per cent level. 
Table 7: The impact of agricultural extension on log value of crop production per hectare of cropped area: with and without farmer ability as measured in June 1997

\begin{tabular}{|c|c|c|c|c|c|c|c|c|c|c|c|c|c|}
\hline & \multicolumn{2}{|l|}{$1992 / 93$} & \multicolumn{2}{|l|}{$1993 / 94$} & \multicolumn{2}{|l|}{$1994 / 95$} & \multicolumn{2}{|l|}{$1995 / 96$} & \multicolumn{4}{|c|}{ Pooled sample } & \multirow[t]{2}{*}{ Fixed effects } \\
\hline & $\begin{array}{l}\text { Without } \\
\text { ability } \\
\text { variable }\end{array}$ & $\begin{array}{l}\text { With } \\
\text { ability } \\
\text { variable }\end{array}$ & $\begin{array}{l}\text { Without } \\
\text { ability } \\
\text { variable }\end{array}$ & $\begin{array}{l}\text { With } \\
\text { ability } \\
\text { variable }\end{array}$ & $\begin{array}{l}\text { Without } \\
\text { ability } \\
\text { variable }\end{array}$ & $\begin{array}{l}\text { With } \\
\text { ability } \\
\text { variable }\end{array}$ & $\begin{array}{l}\text { Without } \\
\text { ability } \\
\text { variable }\end{array}$ & $\begin{array}{l}\text { With } \\
\text { ability } \\
\text { variable }\end{array}$ & $\begin{array}{l}\text { Without } \\
\text { ability } \\
\text { variable or } \\
\text { village } \\
\text { dummies }\end{array}$ & $\begin{array}{l}\text { With ability } \\
\text { variable, } \\
\text { without } \\
\text { village } \\
\text { dummies }\end{array}$ & $\begin{array}{l}\text { Without } \\
\text { ability } \\
\text { variable } \\
\text { and } \\
\text { village } \\
\text { dummies }\end{array}$ & $\begin{array}{l}\text { With } \\
\text { ability } \\
\text { variable } \\
\text { and } \\
\text { village } \\
\text { dummies }\end{array}$ & \\
\hline $\begin{array}{l}1-2 \\
\text { extension } \\
\text { visits }\end{array}$ & $\begin{array}{l}0.129 \\
(1.524)\end{array}$ & $\begin{array}{l}0.100 \\
(1.178)\end{array}$ & $\begin{array}{l}0.210 * * \\
(2.237)\end{array}$ & $\begin{array}{l}0.178 \\
(1.652)\end{array}$ & $\begin{array}{l}-0.129 \\
(-0.701)\end{array}$ & $\begin{array}{l}-0.092 \\
(0.593)\end{array}$ & $\begin{array}{l}0.218^{*} \\
(1.836)\end{array}$ & $\begin{array}{l}0.215^{*} \\
(1.945)\end{array}$ & $\begin{array}{l}0.178^{* * *} \\
(3.138)\end{array}$ & $\begin{array}{l}0.170 * * \\
(2.842)\end{array}$ & $\begin{array}{l}0.168 * * * \\
(3.148)\end{array}$ & $\begin{array}{l}0.161 * * \\
(2.836)\end{array}$ & $\begin{array}{l}0.160 \\
(2.714)^{* *}\end{array}$ \\
\hline $\begin{array}{l}\text { Extension } \\
\text { workers' } \\
\text { assessment } \\
\text { of farmer } \\
\text { ability }\end{array}$ & & $\begin{array}{l}0.505 * * * \\
(3.107)\end{array}$ & & $\begin{array}{l}0.674 * * * \\
(5.702)\end{array}$ & & $\begin{array}{l}0.476 \\
(1.652)\end{array}$ & & $\begin{array}{l}0.625^{* * *} \\
(3.361)\end{array}$ & & $\begin{array}{l}0.580 * * * \\
(6.924)\end{array}$ & & $\begin{array}{l}0.575^{* * *} \\
(8.288)\end{array}$ & \\
\hline
\end{tabular}

Notes:

1. Extension workers' assessment of farmer ability as a continuous variable, from 0.25 (poorest) to 1 (excellent).

2. Regressors included but not reported are: log of capital, span of trained oxen, span of trained oxen squared, log of labour, log of area cropped, average years of education among adults, dummy variables for land sloped, soils are sandy, soils are clay, distance from plot to homestead, distance from homestead to market and log of rainfall.

3. Pooled and fixed effects estimates include year dummies.

4. Sample sizes: 1992/93 - 225; 1993/94 - 221; 1994/95 - 160; 1995/96 - 241; pooled sample - 847.

5. F-statistic and absolute values of $t$ statistics are calculated from robust standard errors in the presence of intra-cluster correlation at the village level (Rogers, 1993).

6. *** significant at the 1 per cent level; ** at the 5 per cent level; * at the 10 per cent level. 
References

Bindlish, V. and R. Evenson. "Evaluation of the performance of T\&V extension in Kenya", World Bank Technical Paper 208, Africa Technical Department Series, World Bank, 1993.

Bindlish, V. and R. Evenson. "The impact of T\&V extension in Africa: The experience of Kenya and Burkina Faso", World Bank Research Observer 12 (2, 1997): 183-201.

Birkhaeuser, D., R. Evenson and G. Feder. "The economic impact of agricultural extension: A review", Economic Development and Cultural Change 39 (3, 1991): 507-521.

Deaton, A. The analysis of household surveys: A microeconomic approach to development policy. Baltimore: Johns Hopkins University Press, 1997.

Evenson, R. "Economic impact studies of agricultural research and extension, mimeo, Yale University, 1998.

Gautam, M. and J.R. Anderson. "Reconsidering the evidence on returns to T\&V extension in Kenya", Policy Research Working Paper 2098, World Bank, 1999.

Gunning, J.W., J. Hoddinott, B. Kinsey and T. Owens. "Revisiting forever gained: Income dynamics in the resettlement areas of Zimbabwe, 1983-1996", Journal of Development Studies 36 (6, 2000): 131-154.

Halvorsen, R. and R. Palmquist. "The interpretation of dummy variables in semi-logarithmic equations", American Economic Review 70 (3, 1980): 473-475.

Rogers, W. "Regression standard errors in clustered samples", STATA Technical Bulletin 13 (1, 1993): 19-23.

Rosenzweig, M. and K. Wolpin, "Evaluating the effects of optimally distributed public programs", American Economic Review 76 (3, 1986): 470-487. 